\title{
Elevation of circulating big endothelin- I : an independent prognostic factor for tumor recurrence and survival in patients with esophageal squamous cell carcinoma Wenjie Jiao*1, Jing $\mathrm{Xu}^{2}$, Jinsheng Zheng ${ }^{3}$, Yi Shen ${ }^{2}$, Lesheng Lin $^{2}$ and Jian $\mathrm{Li}^{1}$
}

Address: ${ }^{1}$ Department of Thoracic Surgery, Peking University First Hospital, Beijing, PR China, ${ }^{2}$ Department of Thoracic Surgery, Committee of Disciplinary Inspection, the Affiliated Hospital of Qingdao University Medical College, Qingdao, PR China and ${ }^{3}$ Department of Thoracic Surgery, Wulanhot Hospital, Wulanhot, PR China

Email: Wenjie Jiao* - jiaowenjie@163.com; Jing Xu - pingguo.pai@163.com; Jinsheng Zheng - doctorjiao@hotmail.com; Yi Shen - yishen@163.com; Lesheng Lin - lin1949@163.com; Jian Li - pku1st@163.com

* Corresponding author

Published: 15 November 2008

BMC Cancer 2008, 8:334 doi:10.1 |86/|47|-2407-8-334
Received: 17 June 2008

Accepted: 15 November 2008

This article is available from: http://www.biomedcentral.com/I47I-2407/8/334

(C) 2008 Jiao et al; licensee BioMed Central Ltd.

This is an Open Access article distributed under the terms of the Creative Commons Attribution License (http://creativecommons.org/licenses/by/2.0), which permits unrestricted use, distribution, and reproduction in any medium, provided the original work is properly cited.

\begin{abstract}
Background: Endothelin(ET) axis plays a key role in many tumor progression and metastasis via various mechanisms such as angiogenesis, mediating extracellular matrix degradation and inhibition of apoptosis. However, there is limited information regarding the clinical significance of plasma big ET-I levels in esophageal cancer patients. Circulating plasma big ET-I levels were measured in patients with esophageal squamous cell carcinoma(ESCC) to evaluate the value of ET-I as a biomarker for predicting tumor recurrence and patients survival.
\end{abstract}

Methods: Preoperative plasma big ET-I concentrations were measured by an enzyme linked immunosorbent assay(ELISA) in 108 ESCC patients before surgery, and then again at $1,2,3,10$ and 30 days after curative radical resection for ESCC. The association between preoperative plasma big ET-I levels and clinicopathological features, tumor recurrence and patient survival, and their changes following surgery were evaluated.

Results: The preoperative plasma big ET-I levels in ESCC patients were significantly higher than those in controls. And there was a significant association between plasma big ET-I levels and disease stage, as well as invasion depth of the tumor and lymph node status. Furthermore, plasma big ET-I levels decreased significantly after radical resection of the primary tumor and patients with postoperative recurrence had significantly higher plasma big ET-I levels than that of patients without recurrence. Finally, the survival rate of patients with higher plasma big ET-I concentrations $(>4.3 \mathrm{pg} / \mathrm{ml})$ was significantly lower than that of patients with lower level $(\leq 4.3 \mathrm{pg} / \mathrm{ml})$. Multivariate regression analysis showed that plasma big ET-I level is an independent prognostic factor for survival in patients with ESCC.

Conclusion: Plasma big ET-I level in ESCC patients may reflect malignancy and predict tumor recurrence and patient survival. Therefore, the preoperative plasma big ET-I levels may be a clinically useful biomarker for choice of multimodality therapy in ESCC patients. 


\section{Background}

The incidence of esophageal cancer shows a striking geographic variation in the world: a 20-fold variation is observed between high-risk China and low-risk western Africa[1]. Recently, advances in surgical techniques and peri-operative management significantly improved the outcome of patients with squamous cell carcinoma of the esophagus. However, the overall survival remains poor and the five year survival rate remains below 30 percent in patients with esophageal cancer after a curative esophagectomy[2-4]. Many results[5-8] demonstrated the prognosis in patients with esophageal cancer mainly depends on tumor stage, but other multiple factors, including age, gender, the size of tumor and some molecular markers, will influence tumor response to therapy. Accurate prognostic factor is essential for selecting patients who are suitable for combined-modality therapy. The use of circulating prognostic biomarkers is a convenient way to achieve the objective[9].

Endothelins(ETs), including ET-1, ET-2 and ET-3, are small 21-residue peptides[10]. There are at least two receptor subtypes, endothelin A receptors(ETAR) and endothelin B receptors(ETBR), belonging to the family of G-protein-linked receptors with seven transmembranespanning domains[11]. The ET-1 gene encodes a precursor peptide, preproendothelin-1, which is cleaved by a neutral endopeptidase to form proendothelin-1 or big ET1. Due to a low circulating concentration and a short plasma half-life (about $1.5 \mathrm{~min}$ ), measurement of plasma ET- 1 concentrations has proven to be difficulty. Big ET-1 is a stable peptide with a plasma half-life of 30 minutes, making the measurement of plasma big ET-1 concentrations a sensitive indicator of endothelin system activation[12,13]. Recent studies [14-18] have suggested that ET-1 may play an important role in tumorigenesis, tumor progression and metastasis presumably by various mechanisms, including mitogenesis, inhibition of apoptosis, angiogenesis and mediating extracellular matrix degradation.

According to our previous study[19], ET-1 can increase the invasive ability of human esophageal cancer cells. However, it is unclear about prognostic significance of preoperative plasma big ET-1 in patients with ESCC. In this study, we evaluated: 1)plasma big ET-1 levels in ESCC patients and in healthy controls, 2) its correlation with clinicopathologic features, tumor recurrence and patient survival, and 3) the effect of surgery on plasma big ET-1 levels.

\section{Methods}

\section{Patient Selection}

The study population consists of 122 consecutive patients who underwent radical resection at our hospital between
March of 2000 and August of 2002. All patients had been confirmed as esophageal squamous cell carcinoma by postoperative histopathologic assessment. Tumor stage was classified by the routine histopathologic assessment according to the UICC TNM staging system [20]. Patients who had received chemotherapy and/or radiotherapy before surgery were excluded from the study. Patients with co-morbid conditions that are associated with elevated ET-1, such as hypertension, cardiac failure, myocardial infarction and rheumatic diseases, were excluded. Moreover, 122 patients were asked about their habits of smoking and drinking. They were divided into three groups stratified by the number of cigarettes per day(cps) defined as non-smoker(have not smoked yet or very rarely tried to smoke), light-smoker(less than 20 cps) and heavysmoker(more than $20 \mathrm{cps}$ ). And the patients were also divided into three groups stratified by ethanol intake levels defined as non-drinker (less than $1 \mathrm{~g} /$ day), lightdrinker (1-50 g/day) and heavy-drinker (more than $50 \mathrm{~g} /$ day). Fourteen patients which were heavy smokers and/or drinkers were excluded in order to avoid potential interference. Out of a total of 122 such patients, 108 patients were the subjects of the present study. There were 78 men and 30 women with a median age of 64.5 (range, 44-79) years.

The control group consisted of 82 age- and sex-matched healthy individuals(median age 65.3 [range, 40-72] years; 44 men and 38 women) without any evidence of disease. Moreover, we also collected data in 26 lightsmokers, 35 heavy-smokers, 32 light-drinkers and 38 heavy-drinkers without ESCC and/or co-morbid conditions. The regional ethics committee approved the project. Patients were followed and the date and cause of death was recorded. The diagnosis of local/regional recurrence and distant metastases were confirmed by histology and/ or imaging findings.

\section{Blood collection and assays}

Peripheral venous blood samples were drawn into sterile glass tubes in the morning between 7 and 8 hours after an overnight fast. All blood samples was collected in EDTA specimen tubes, placed immediately into an ice bag and centrifuged at 2,000 rpm for 10 minutes at $4{ }^{\circ} \mathrm{C}$ within 15 minutes of blood collection. Plasma was separated, aliquoted, and stored at $-70^{\circ} \mathrm{C}$ until assay. Plasma samples were collected and stored on admission and 1,2,3,10 and 30 days following surgery. Plasma big ET-1 concentrations were measured using a one-step sandwich enzyme immunoassay kit (Biomedica, Vienna, Austria) in accordance with the manufacturer's protocol. The kit consisted of purified polyclonal antibody and monoclonal detection antibody highly specific for big ET-1. Big ET-1 binds to the pre-coated antibody and forms a sandwich with the detection antibody. Plasma big ET-1 concentrations were calcu- 
lated by extrapolation from a standard curve. A separate standard curve was constructed for each ELISA batch. All standards and patient samples were analyzed in duplicate and the mean value was taken.

\section{Statistical analysis}

The values of the plasma big ET- 1 was written as mean \pm standard deviation. T test and ANOVA were used to evaluate differences between multiple groups, unpaired and paired observations, respectively. Kaplan-Meier survival curves and the log rank test were used to analyses survival differences. Univariate and multivariate analyses (Cox's proportional hazard) of all clinicopathological variables were performed using SPSS version 10.1 (SPSS Inc, Chicago, IL, USA). A $p$ value of less than 0.05 was considered significant.

\section{Results}

\section{I) Preoperative plasma big ET-I levels}

Preoperative plasma big ET-1 levels $(4.70 \pm 0.81 \mathrm{pg} / \mathrm{mL})$ in patients with ESCC were significantly higher than those in controls $(3.31 \pm 0.78 \mathrm{pg} / \mathrm{mL}, P<0.001)$, light-smok$\operatorname{ers}(3.44 \pm 0.71, \mathrm{P}=0.005)$ and light-drinker(3.36 \pm 0.83 , $\mathrm{P}=0.003)$, heavy-smokers(4.12 $\pm 0.56, \mathrm{P}=0.020)$ and heavy-drinkers $(3.86 \pm 0.75, \mathrm{P}=0.011)$. Moreover, the levels in controls were significantly lower than those in heavy-smokers $(P=0.010)$ and heavy-drinkers $(P=0.038)$ without ESCC, and were no statistically different compared to the levels of light-smoker $(\mathrm{P}=0.250)$ and lightdrinker $(P=0.382)$.

The relationships between plasma big ET-1 levels and clinicopathologic variables are shown in Table 1 . The correlation between plasma big ET-1 levels and the invasion depth of the tumor was statistically significant by ANOVA. Patients with tumors penetrating the muscle (T3) had significantly higher plasma big ET-1 levels when compared to those with tumors limited to the mucosa, submucosa or muscle(T1/2). And patients with lymph node metastasis had significantly higher big ET-1 levels when compared with those without metastatic disease. Moreover, there was a significant correlation between plasma big ET-1 lev-

Table I: Correlation between preoperative plasma big ET-I levels and clinicopathologic variables in ESCC patients

\begin{tabular}{|c|c|c|c|}
\hline Characteristic & Number of patients (n) & Preoperative plasma big ET-I levels (pg/ml) & $P$ value \\
\hline \multicolumn{4}{|l|}{ Gender } \\
\hline Male & 78 & $4.62 \pm 0.72$ & 0.285 \\
\hline Female & 30 & $4.85 \pm 0.63$ & \\
\hline \multicolumn{4}{|l|}{ Age, y } \\
\hline$\leq 60 \mathrm{yrs}$ & 41 & $4.67 \pm 0.55$ & 0.876 \\
\hline$>60$ yrs & 67 & $4.72 \pm 0.86$ & \\
\hline \multicolumn{4}{|l|}{ Smoking } \\
\hline Light-smoker & 42 & $4.78 \pm 0.39$ & 0.386 \\
\hline Non-smoker & 66 & $4.65 \pm 0.64$ & \\
\hline \multicolumn{4}{|l|}{ Drinking } \\
\hline Light-drinker & 35 & $4.73 \pm 0.27$ & 0.674 \\
\hline Non-drinker & 73 & $4.68 \pm 0.50$ & \\
\hline \multicolumn{4}{|l|}{ Site of tumor } \\
\hline upper & 12 & $4.75 \pm 0.91$ & 0.763 \\
\hline Middle & 57 & $4.70 \pm 0.57$ & \\
\hline Lower & 39 & $4.69 \pm 0.83$ & \\
\hline \multicolumn{4}{|c|}{ Tumor differenciation } \\
\hline Well & 30 & $4.61 \pm 0.54$ & 0.354 \\
\hline Moderate & 48 & $4.64 \pm 0.68$ & \\
\hline Poor & 30 & $4.88 \pm 0.47$ & \\
\hline \multicolumn{4}{|l|}{ Tumor class } \\
\hline $\mathrm{TI}$ & 33 & $4.42 \pm 0.61$ & 0.001 \\
\hline $\mathrm{T} 2$ & 38 & $4.60 \pm 0.34$ & \\
\hline $\mathrm{T} 3$ & 37 & $5.01 \pm 0.84$ & \\
\hline $\mathrm{T} 4$ & 0 & 0 & \\
\hline \multicolumn{4}{|c|}{ Lymph node metastasis } \\
\hline No & 63 & $4.45 \pm 0.59$ & $<0.001$ \\
\hline NI & 45 & $5.06 \pm 0.63$ & \\
\hline \multicolumn{4}{|l|}{ Stage } \\
\hline 1 & 28 & $4.41 \pm 0.52$ & 0.003 \\
\hline ॥ & 48 & $4.68 \pm 0.76$ & \\
\hline III & 32 & $5.25 \pm 0.82$ & \\
\hline IV & 0 & 0 & \\
\hline
\end{tabular}


els and disease stage, with higher big ET-1 levels detected as the disease stage increased.

There were no significant associations between plasma big ET-1 levels and gender, age, tumor location and degree of differentiation.

\section{2) The effect of surgery on plasma big ET-I Levels}

The effect of surgical resection of the tumor was evaluated by sequential measurement of plasma big ET-1 levels before surgery and at 1,2,3,10 and 30 postoperative days(POD) following surgery. Radical resection including subtotal esophagectomy and removal of the regional lymph nodes (two-field lymph node dissection) was performed in all 108 patients. The plasma big ET-1 levels on the first and second postoperative day increased significantly compared with preoperative levels in 108 patients, but decreased on the 3rd POD with no significant difference compared to the pre-operative levels. And then, there was a subsequent decrease with the 10 day postoperative levels being significantly lower than preoperative levels. The plasma big ET-1 levels at 30 days remain stable when compared with 10 days postoperative values $(\mathrm{P}=$ 0.273).(Figure 1)

\section{3) The overview of follow-up}

All patients lived at least 30 days after surgery, and were followed-up using a standard protocol after discharge from the hospital. The mean follow-up period was 34.2 months (7 60 months). Cancer-specific survival was calculated from the date of operation until date of death or last follow-up. Survival was censored for patients who died without disease progression. During the study, 63 patients died from ESCC progression (including 19 patients who developed local/regional recurrences and 44 patients who developed distant recurrences) and 45 patients remained alive, 7 of them with documented tumor recurrence.

\section{4) Correlations between preoperative plasma big ET-I levels and patients survival}

Because $4.3 \mathrm{pg} / \mathrm{mL}$ was the upper limit of plasma big ET1 concentrations in healthy controls $(2.9 \sim 4.3 \mathrm{pg} / \mathrm{mL})$, the value was regarded as a threshold according to previous report $[9,12]$. Elevated plasma big ET-1 levels were found in $71(65.7 \%)$ patients. The overall survival rate of patients with higher plasma big ET-1 concentrations $(>4.3 \mathrm{pg} / \mathrm{ml})$ was significantly lower than that of patients with lower level $(\leq 4.3 \mathrm{pg} / \mathrm{ml})$.(Figure 2 )

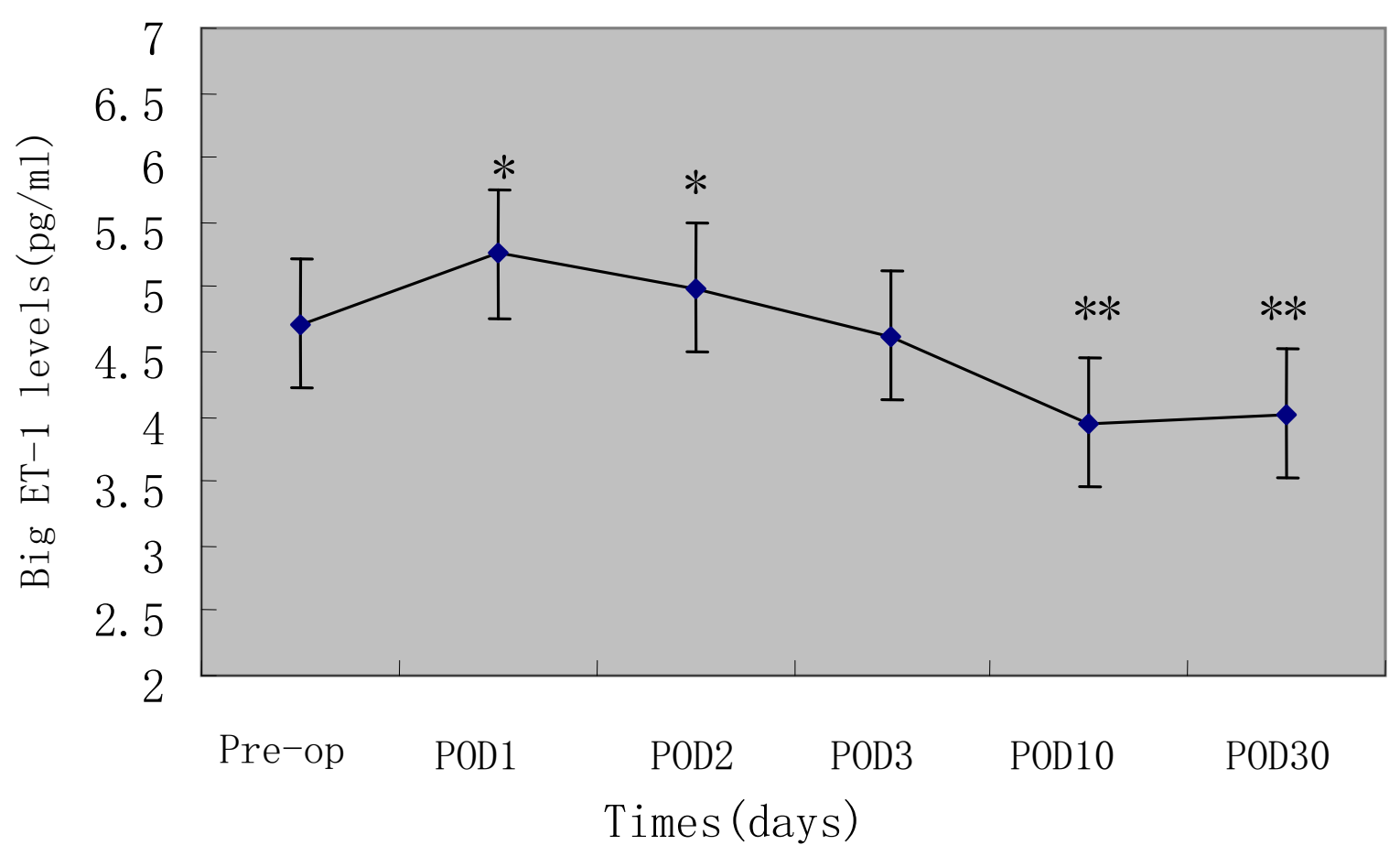

Figure I

Changes in plasma big ET-I levels following esophagectomy. *elevated on PODI and POD2 $(\mathrm{P}<0.00 \mathrm{I})$ and ** reduced on PODI0 and POD30(P < 0.00I) compared with preoperative levels. 
Prognostic variables evaluated in a univariate analysis included age, gender, tumor location, differentiation, $\mathrm{T}$ class, lymph node status, TNM stage and preoperative plasma big ET-1 level. (Table 2) Multivariate regression analysis identified four variables, $T$ class, lymph node status, TNM stage and preoperative plasma big ET-1 concentration as having independent prognostic value for overall survival. (Table 3 )

\section{5) Correlations among preoperative plasma big ET-I levels, tumor recurrence and survival}

Patients with recurrence had significantly higher preoperative plasma big ET-1 levels than patients without recurrence $(5.42 \pm 0.66 \mathrm{pg} / \mathrm{ml}$ versus $4.46 \pm 0.48 \mathrm{pg} / \mathrm{ml}, \mathrm{P}=$ $0.002)$. About $78.6 \%(55 / 70)$ patients with tumor recur- rence remained high plasma big ET-1 level $(>4.3 \mathrm{pg} / \mathrm{ml})$ when tumor recurrence were found. Moreover, in the patients with tumor local-regional and/or distant recurrence, the disease-free survival rate of patients with elevated plasma big ET- 1 concentrations $(>4.3 \mathrm{pg} / \mathrm{ml})$ was significantly lower than that of patients with lower level $(\leq$ $4.3 \mathrm{pg} / \mathrm{ml}$ ).(Figure 3 )

\section{Discussion}

To date, pathologic stage is the most valuable single prognostic attribute in esophageal cancer patients. In the present study, we evaluated preoperative plasma big ET-1 levels in healthy controls and in ESCC patients using a validated ELISA. Our study shows a marked difference between preoperative plasma big ET-1 concentrations in

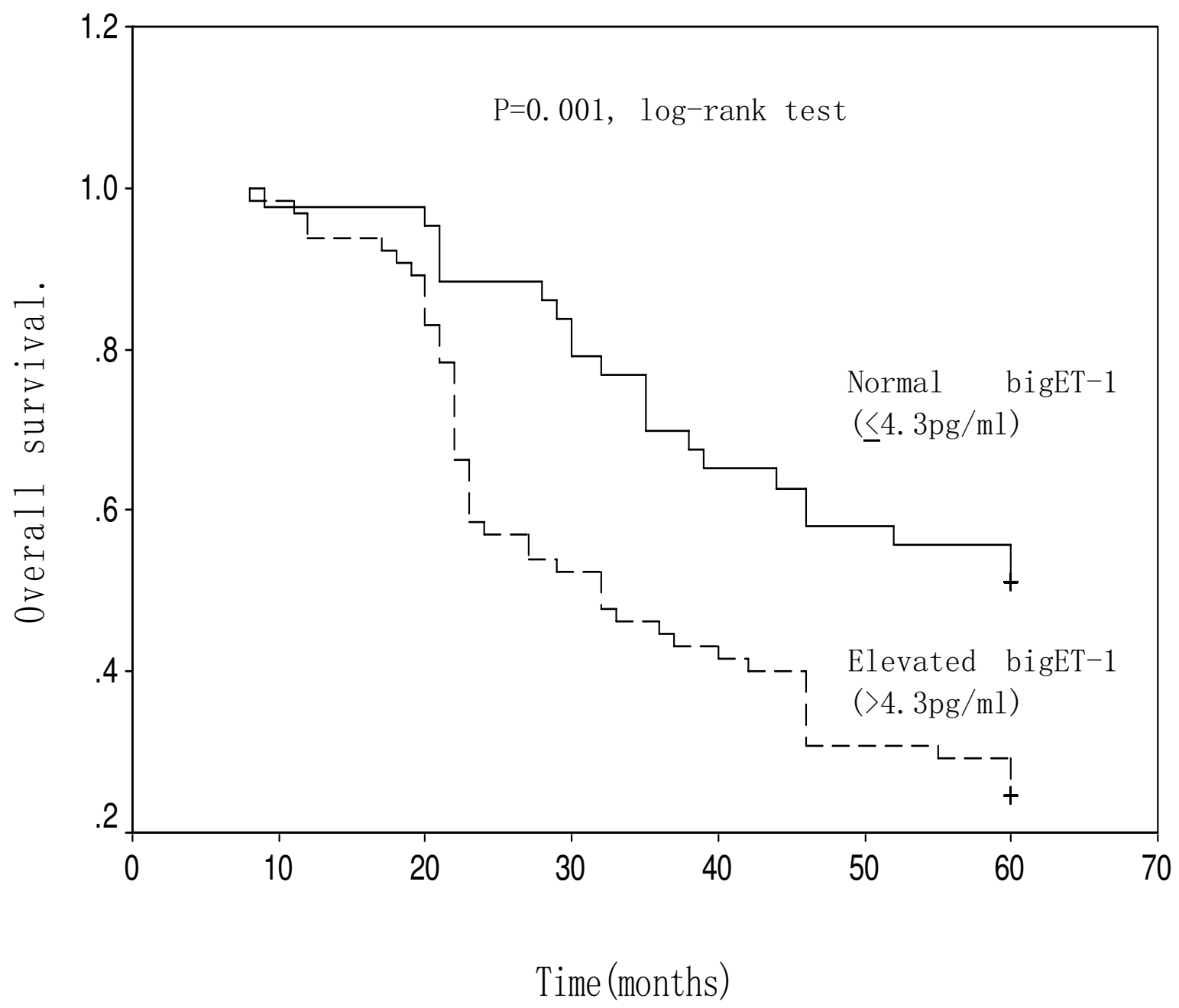

Figure 2

Kaplan-Meier survival curve in relation to preoperative plasma big ET-I levels in patients with ESCC. The overall survival of patients with elevated big ET-I levels was significantly lower than that of patients with normal levels(log-rank test $P=0.00 I)$. 
Table 2: Univariate analysis for predictors of overall survival in patients with ESCC

\begin{tabular}{|c|c|c|c|}
\hline Variable & Hazard Ratio & $95 \%$ Confidence Interval & $P$ value \\
\hline Age $(>60$ vs. $\leq 60)$ & 0.834 & $0.512-1.357$ & 0.834 \\
\hline Gender (male vs. female) & 1.183 & $0.727-1.924$ & 0.499 \\
\hline Site of tumor (upper vs. middle vs. lower) & 1.310 & $0.916-1.872$ & 0.139 \\
\hline Differenciation (well vs. moderate vs. poor) & 1.084 & $0.799-1.470$ & 0.604 \\
\hline Tumor class (TI vs. T2 vs. T3 vs. T4) & 2.763 & $1.632-4.854$ & 0.008 \\
\hline Lymph node status (No vs. NI) & 2.978 & $1.541-3.647$ & 0.010 \\
\hline Stage (I vs. II vs. III vs. IV) & 3.037 & $1.45 \mathrm{I}-4.860$ & $<0.001$ \\
\hline Plasma big ET-I levels (normal vs. elevated) & 2.494 & $1.302-3.806$ & 0.002 \\
\hline
\end{tabular}

ESCC patients when compared with age and sex-matched healthy controls, with a significant association between these levels and tumor invasion depth, lymph node status and TNM stage. Univariate and multivariate survival analysis confirmed that pre-operative plasma big ET-1 level were an independent predictor of survival in patients with ESCC.

Some findings[21-24] suggest that ET-1 may act as an autocrine or paracrine growth factor mediating through its receptor, ETAR or ETBR. It is well established that endothelin axis plays an important role in a series of events relating with tumor development, including mitogenesis[25,26] and escape from apoptosis[27,28]. Moreover, ET-1 expression has been linked to induction of endothelial cell growth, angiogenesis[29-31] and epithelial-to-mesenchymal transition[32-34] resulting in an increased invasiveness and metastases of some tumors. ET-1 expression in ESCC has been associated with its prognostic significance[35]. Our findings are in agreement with the observations and correlate preoperative plasma big ET-1 levels with cancer-specific survival. Based on our results, we identified elevated level of preoperative plasma big ET-1 could act as a marker of aggressive disease and poor survival in ESCC. We speculate that increased plasma big ET-1 level may indicate more tumor load and/ or unidentified micrometastatic disease, predicting a poor survival in patients.

In our study, the mean plasma big ET-1 levels were markedly increased on the 1st and 2nd POD in ESCC patients. The phenomenon may partly contribute to a compensatory response to surgical stress, for example, the reduction of local blood flow in nonvital organs so as to increase the blood flow in vital organs[36]. Several prior reports[3739] suggest that tissue damage, ischemia and surgical stress during operation could raise circulating ET-1 levels, and the elevated ET-1 levels related to surgery frequently peak between 1 and 12 hours in the immediate post-operative period and declined gradually thereafter. On the 3rd POD, the plasma big ET-1 levels declined, but were no statistically different compared to the pre-operative levels. It implies that the increasing levels of big ET- 1 as response to surgical stress were lessen. On the 10th and 30th POD, these levels declined significantly compared to pre-operative levels. Ferrari-Bravo[40] and Teng[41] also reported that postoperative plasma big ET-1 level markedly decreased compared with preoperative concentrations in patients with gastric carcinoma, and concluded that ET-1 may be secreted by the cancer cell and the ET- 1 concentration will fall in when the tumor is removed. These findings $[35,40,41]$, along with our results, suggest that plasma big ET-1 might be able to be used as a measure of surgical completeness.

During the study, preoperative plasma big ET-1 levels were an important independent prognostic factor for postoperative tumor recurrence in patients with ESCC. Those patients with recurrence had significantly higher preoperative plasma big ET-1 levels than patients without recurrence and the overall and disease-free survival rate of patients with elevated plasma big ET-1 concentrations was significantly lower than that of patients with normal level. Our findings suggest that increased plasma big ET-1 level may indicate unidentified micrometastatic disease, and may be used for predicting tumor recurrence in a proportion of patients with ESCC. Postoperative tumor recurrence is not uncommon even in patients undergoing a

Table 3: Multivariate analysis for predictors of overall survival in patients with ESCC

\begin{tabular}{lccc}
\hline Variable & Hazard Ratio & 95\% Confidence Interval & P value \\
\hline Tumor class & 2.878 & $1.805-4.576$ & 0.010 \\
Lymph node status & 2.921 & $1.951-3.988$ & 0.015 \\
Stage & 3.083 & $1.259-5.731$ & 0.002 \\
Plasma big ET-I levels & 2.629 & $1.375-4.054$ & 0.003 \\
\hline
\end{tabular}




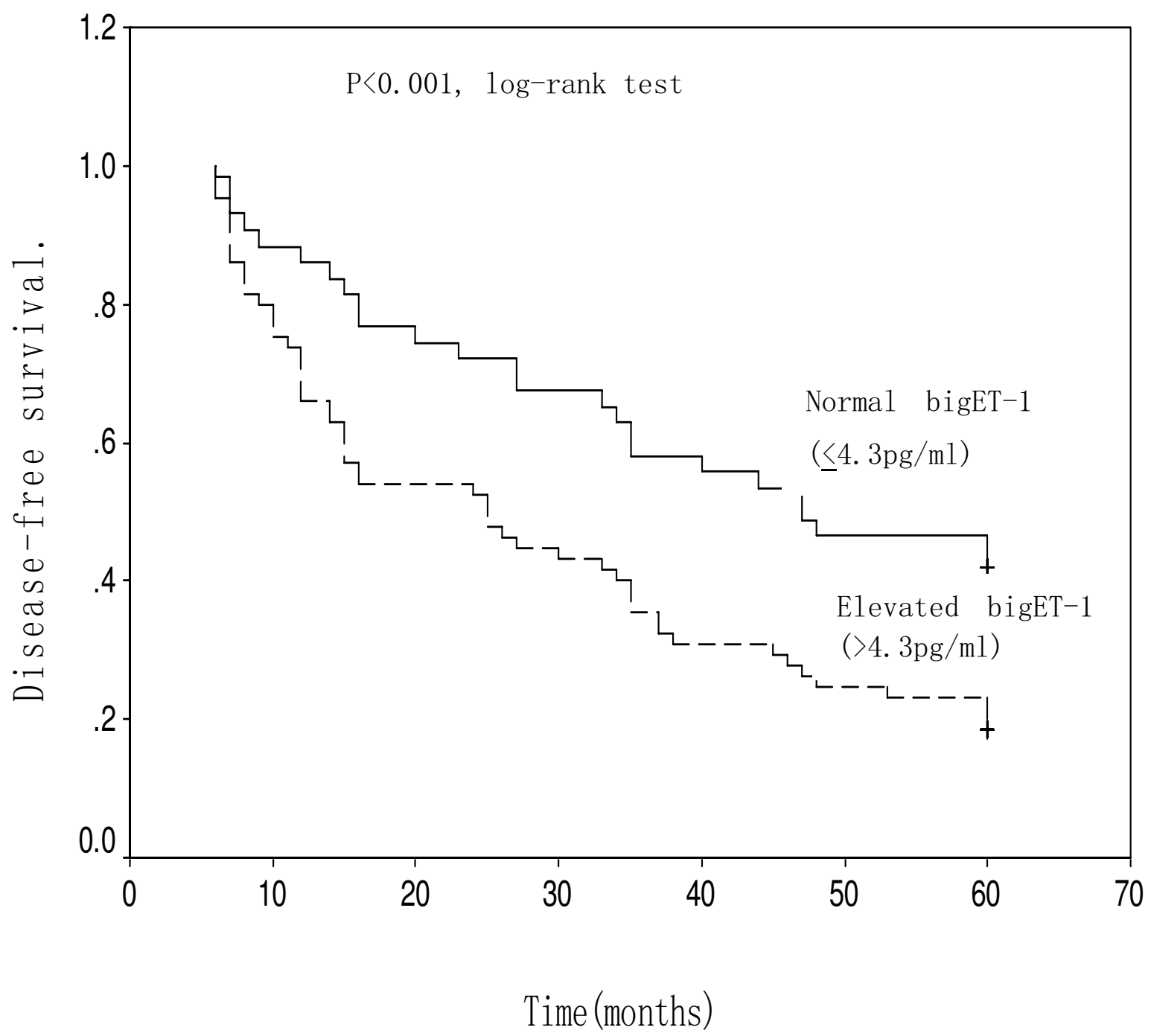

Figure 3

Kaplan-Meier survival curve in relation to preoperative plasma big ET-I levels in patients with ESCC. The disease-free survival of patients with elevated big ET-I levels was significantly lower than that of patients with normal levels(logrank test $\mathrm{P}<0.00 \mathrm{I}$ ).

curative resection for localized resectable esophageal cancer. Micrometastatic tumor cells to either lymph nodes or distant organs which cannot be detected by preoperative imaging techniques may be attributed to such tumor distant failure. It is logical to expect a decline in tumor recurrence with the use of multiple therapy in part of high-risk patients with ESCC. To sterilize occult micrometastases in the distant organs, adjuvant chemotherapy either alone or in combination with radiotherapy is now commonly performed in patients with esophageal cancer either before or after an esophagectomy in an attempt to improve both disease-relapse control and long-term survival[42]. 


\section{Conclusion}

In conclusion, this study has demonstrated elevated plasma big ET-1 levels in ESCC patients when compared with normal controls. Preoperative plasma big ET-1 concentration decreases significantly following radical resection of the primary tumor and is an independent prognostic factor for patient survival. Preoperative plasma big ET-1 concentration can be used for predicting tumor recurrence and may be a clinically useful biomarker for choice of multimodality therapy in ESCC patients.

\section{Competing interests}

The authors declare that they have no competing interests.

\section{Authors' contributions}

JW carried out the design of the study, the ELISA studies, follow-up and drafted the manuscript. XJ and ZJ participated in the design of the study and performed the statistical analysis. SY, LL and LJ participated in its design and coordination. All authors read and approved the final manuscript.

\section{References}

I. Parkin DM, Bray F, Ferlay J, Pisani P: Global cancer statistics, 2002. CA Cancer J Clin 2005, 55:74-108.

2. Portale G, Hagen JA, Peters JH, Chan LS, DeMeester SR, Gandamihardja TA, DeMeester TR: Modern 5-year survival of resectable esophageal adenocarcinoma: single institution experience with 263 patients. J Am Coll Surg 2006, 202:588-596.

3. Enzinger PC, Mayer RJ: Esophageal cancer. N Engl J Med 2003, 349:224I-2252.

4. Shiozaki H, Doki Y, Kawanishi K, Shamma A, Yano M, Inoue M, Monden M: Clinical application of malignancy potential grading as a prognostic factor of human esophageal cancers. Surgery 2000, I 27:552-56I.

5. Korst RJ, Kansler AL, Port JL, Lee PC, Kerem Y, Altorki NK: Downstaging of $\mathbf{T}$ or $\mathbf{N}$ predicts long-term survival after preoperative chemotherapy and radical resection for esophageal carcinoma. Ann Thorac Surg 2006, 82:480-484.

6. Tajima T, Mukai M, Sato S, Ninomiya H, Wakui K, Komatsu N, Tsuchiya $K$, Nakasaki $H$, Makuuchi $H$ : Predicting recurrence and metastasis of primary esophageal cancer with or without lymph node metastasis. Oncol Rep 2006, I5:809-8I4.

7. Hosch SB, Stoecklein NH, Pichlmeier U, Rehders A, Scheunemann P, Niendorf A, Knoefel WT, lzbicki JR: Esophageal cancer: the mode of lymphatic tumor cell spread and its prognostic significance. J Clin Oncol 200I, 19:1970-1975.

8. Schneider PM, Baldus SE, Metzger R, Kocher M, Bongartz R, Bollschweiler E, Schaefer H, Thiele J, Dienes HP, Mueller RP, Hoelscher AH: Histomorphologic tumor regression and lymph node metastases determine prognosis following neoadjuvant radiochemotherapy for esophageal cancer: implications for response classification. Ann Surg 2005, 242:684-92.

9. Mai HQ, Zeng ZY, Zhang CQ, Feng KT, Guo X, Mo HY, Deng MQ, Min HQ, Hong MH: Elevated Plasma Big ET-I Is Associated with Distant Failure in Patients with Advanced-Stage Nasopharyngeal Carcinoma. Cancer 2006, 106:1548-I553.

10. Inoue A, Yanagisawa M, Kimura S, Kasuya Y, Miyauchi T, Goto K, Masaki $T$ : The human endothelin family: three structurally and pharmacologically distinct isopeptides predicted by three separate genes. Proc Natl Acad Sci USA 1989, 86:2863-2867.

II. Ahmed SI, Thompson J, Coulson JM, Woll PJ: Studies on the expression of endothelin, its receptor subtypes, and converting enzymes in lung cancer and in human bronchial epithelium. Am J Respir Cell Mol Biol 2000, 22:422-43I.

12. Everson NW, Elahi MM: Prognosis of Colorectal Cancer Patients with Elevated Endothelin-I Concentrations. Asian J Surg 2004, 27:4-9.
13. Hemsen A, Ahlborg G, Ottosson-Seeberger A, Lundberg JM: Metabolism of big endothelin-I (I-38) and (22-38) in the human circulation in relation to production of endothelin-I (I-2I). RegulPept 1995, 55:M287-297.

14. Wulfing P, Kersting C, Tio J, Fischer RJ, Wulfing C, Poremba C, Diallo R, Bocker W, Kiesel L: Endothelin-I-, Endothelin-A-, and Endothelin-B-Receptor Expression Is Correlated with Vascular Endothelial Growth Factor Expression and Angiogenesis in Breast Cancer. Clin Cancer Res 2004, 10:2393-2400.

15. Spinella F, Rosano L, Di Castro V, Natali PG, Bagnato A: EndothelinI induces vascular endothelial growth factor by increasing hypoxia-inducible factor $\mathrm{I} \alpha$ in ovarian cancer cells. J Biol Chem 2002, 277:27850-27855.

16. Salani D, Taraboletti G, Rosano L, Di Castro V, Borsotti P, Giavazzi $R$, Bagnato $A$ : Endothelin-I induces an angiogenic phenotype in cultured endothelial cells and stimulates neovascularization in vivo. Am J Pathol 2000, I57:1703-171I.

17. Del Bufalo D, Di Castro V, Biroccio A, Varmi M, Salani D, Rosano L, Triciuoglio D, Spinella F, Bagnato A: Endothelin-I protects ovarian carcinoma cells against paclitaxel-induced apoptosis: requirement for Akt activation. Mol Pharmacol 2002, 61:524-532.

18. Rosano L, Varmi M, Salani D, Di Castro V, Spinella F, Natali PG, Bagnato $A$ : Endothelin- $I$ induces tumor proteinase activation and invasiveness of ovarian carcinoma cells. Cancer Res 200I, 6 I:8340-8346.

19. Jiao WJ, Xu J, Pan H, Wang TY, Shen Y: Effect of endothelin-I in esophageal squamous cell carcinoma invasion and its correlation with cathepsin B. World J Gastroenterol 2007, I 3:4002-4005.

20. Sobin LH, Wittekind C: TNM Classification of Malignant Tumours. 5th edition. New York, Wiley-Liss

21. Boldrini L, Gisfredi S, Ursino S, Faviana P, Lucchi M, Melfi F, Mussi A, Basolo F, Fontanini G: Expression of endothelin- $I$ is related to poor prognosis in non-small cell lung carcinoma. Eur J Cancer 2005, 41:2828-2835.

22. Donckier JE, Michel L, Van Beneden R, Delos M, Havaux X: Increased expression of endothelin-I and its mitogenic receptor ETA in human papillary thyroid carcinoma. Clin Endocrinol (Oxf) 2003, 59:354-360.

23. Venuti A, Salani D, Manni V, Poggiali F, Bagnato A: Expression of endothelin I and endothelin A receptor in HPV-associated cervical carcinoma: new potential targets for anticancer therapy. FASEB J 2000, 14:2277-2283.

24. Wulfing P, Tio J, Kersting C, Sonntag B, Buerger H, Wulfing C, Euler $U$, Boecker W, Tulusan AH, Kiesel L: Expression of endothelin-Areceptor predicts unfavourable response to neoadjuvant chemotherapy in locally advanced breast cancer. $\mathrm{Br} J$ Cancer 2004, 9 I:434-440.

25. Kawanabe Y, Hashimoto N, Masaki T: Effects of extracellular $\mathrm{Ca2}+$ influx on endothelin-I-induced intracellular mitogenic cascades in C6 glioma cells. Eur J Pharmacol 2002, 435: I I9-I 23.

26. Kawanabe $Y$, Hashimoto N, Masaki T: B 103 neuroblastoma cells predominantly express endothelin ET(B) receptor; effects of extracellular $\mathrm{Ca}(2+)$ influx on endothelin-I-induced mitogenesis. Eur J Pharmacol 200I, 425:173-179.

27. Nelson JB, Udan MS, Guruli G, Pflug BR: Endothelin-I inhibits apoptosis in prostate cancer. Neoplasia 2005, 7:631-637.

28. Duan J, Dai S, Fang CX, Sun R, Shavali S, Sharma SK, Ebadi M, Ren J: Phytoestrogen alpha-zearalanol antagonizes homocysteineinduced imbalance of nitric oxide/endothelin- $I$ and apoptosis in human umbilical vein endothelial cells. Cell Biochem Biophys 2006, 45: I37- I 45.

29. Bhargava S, Stummeyer T, Hotz B, Hines OJ, Reber HA, Buhr HJ, Hotz HG: Selective inhibition of endothelin receptor $\mathbf{A}$ as an anti-angiogenic and anti-proliferative strategy for human pancreatic cancer. J Gastrointest Surg 2005, 9:703-709.

30. Medinger M, Adler CP, Schmidt-Gersbach C, Soltau J, Droll A, Unger C, Drevs J: Angiogenesis and the ET-I/ETA receptor system: immunohistochemical expression analysis in bone metastases from patients with different primary tumors. Angiogenesis 2003, 6:225-23I.

31. Knowles J, Loizidou M, Taylor I: Endothelin-I and angiogenesis in cancer. Curr Vasc Pharmacol 2005, 3:309-3।4.

32. Felx M, Guyot MC, Isler M, Turcotte RE, Doyon J, Khatib AM, Leclerc S, Moreau A, Moldovan F: Endothelin-I (ET-I) promotes MMP2 and MMP-9 induction involving the transcription factor 
NF-kappaB in human osteosarcoma. Clin Sci(Lond) 2006, I I 0:645-654.

33. Rosano L, Spinella F, Di Castro V, NIcotra MR, Dedhar S, de Herreros AG, Natali PG, Bagnato A: Endothelin-I promotes epithelial-tomesenchymal transition in human ovarian cancer cells. Cancer Res 2005, 65: I 1649-I I 657.

34. Hagemann T, Binder C, Binder L, Pukrop T, Trumper L, Grimshaw MJ: Expression of endothelins and their receptors promotes an invasive phenotype of breast tumor cells but is insufficient to induce invasion in benign cells. DNA Cell Biol 2005, 24:766-776.

35. Ishibashi Y, Hanyu N, Nakada K, Suzuki Y, Yamamoto T, Takahashi T, Kawasaki N, Kawakami M, Matsushima M, Urashima M: Endothelin protein expression as a significant prognostic factor in oesophageal squamous cell carcinoma. Eur J Cancer 2003, 39:|409-|4|5.

36. Onizuka M, Miyauchi T, Mitsui K, Suzuki N, Masaki T, Goto K, Hori $M$ : Endothelin-I mediates regional blood flow during and after pulmonary operations. J Thorac Cardiovasc Surg 1992, 104:1696-1701.

37. Battistini B, D'Orleans-Juste P, Sirois P: Endothelins: circulating plasma levels and presence in other biologic fluids. Lab Invest 1993, 68:600-628.

38. Shirakami G, Magaribuchi T, shingu K, Saito Y, O'higashi T, Nakao K, Mori K: Effects of anesthesia and surgery on plasma endothelin levels. Anesth Analg 1995, 80:449-453.

39. Itoh K, Goseki N, Endo M, Hirata Y, Marumo F: Intraoperative hemorrhage affects endothelin-I concentrations. Am J Gastroenterol 1991, 86: II8-II9.

40. Ferrari-Bravo A, Franciosi C, Lissoni P, Fumagalli L, Uggeri F: Effects of oncological surgery on endothelin- $I$ secretion in patients with operable gastric cancer. Int / Biol Markers 2000, I 5:56-57.

4I. Teng XJ, Shen ZX, Xiang JJ, Shen L, Yuan L, Guo J, Wang XL: Preand post-operative plasma big endothelin-I levels in patients with gastric carcinoma undergoing radical gastrectomy. Anticancer Res 2006, 26:2503-2507.

42. Nishimaki T, Shimoji $H$, Sunagawa $H$ : Recent Changes and the Future Roles of Esophageal Cancer Surgery. Ann Thorac Cardiovasc Surg 2004, 10:324-332.

\section{Pre-publication history}

The pre-publication history for this paper can be accessed here:

\section{http://www.biomedcentral.com/1471-2407/8/334/pre}

pub

Publish with Bio Med Central and every scientist can read your work free of charge

"BioMed Central will be the most significant development for disseminating the results of biomedical research in our lifetime. "

Sir Paul Nurse, Cancer Research UK

Your research papers will be:

- available free of charge to the entire biomedical community

- peer reviewed and published immediately upon acceptance

- cited in PubMed and archived on PubMed Central

- yours - you keep the copyright 